\title{
Latter-day Saint Children and Youth in America
}

David C. Dollahite

Brigham Young University - Provo, david_dollahite@byu.edu

Follow this and additional works at: https://scholarsarchive.byu.edu/facpub

Part of the Other Social and Behavioral Sciences Commons

\section{Original Publication Citation}

Dollahite, D. C. (2009). Latter-day Saint children and youth in America. In D. S. Browning \& B.

Miller-McLemore (Eds.), Children and Childhood in American Religions (pp. 102-118).

Piscataway, NJ: Rutgers University Press.

\section{BYU ScholarsArchive Citation}

Dollahite, David C., "Latter-day Saint Children and Youth in America" (2009). Faculty Publications. 4993. https://scholarsarchive.byu.edu/facpub/4993

This Book Chapter is brought to you for free and open access by BYU ScholarsArchive. It has been accepted for inclusion in Faculty Publications by an authorized administrator of BYU ScholarsArchive. For more information, please contact ellen_amatangelo@byu.edu. 


\title{
6
}

\section{Latter-day Saint Children and Youth in America}

\author{
DAVID C. DOLLAHITE
}

Some of the concepts of the view of childhood held by the Latter-day Saints can be found in stories told about the early life of their founder and first prophet, Joseph Smith. Brother Joseph, as he was known to the Saints, often took time to play games with children and youth. Some Mormons, with their early American sense of propriety about religious leaders, were troubled by Joseph's playful nature. One day a Brother Wakefield came to the Prophet's home to discuss church business. He was told that Brother Joseph was translating the word of God. Brother Wakefield waited some time and when the Prophet appeared he immediately began playing with a group of children. Brother Wakefield considered this action so inconsistent with the calling of a prophet that he left Mormonism.

Joseph's special concern for the spiritual and social well-being of children and youth perhaps derived from his own experiences as a youth. He was very young when he began his earnest search for religious truth and received heavenly manifestations. Religious controversy swelled in the area where he grew up as leaders and members of various churches vied for converts and contended hotly with those of other faiths. As a fourteenyear-old youth, he prayed for answers and received a vision in which he saw God the Father and Jesus, who told him not to join any of these churches. As Joseph told others of his vision, intense persecution from those in his village of Palmyra, New York, followed. But he continued to affirm that he had seen God. He said: 
Having been forbidden [by God] to join any of the religious sects of the day, and being of very tender years, and persecuted by those who ought to have been my friends and to have treated me kindly, and if they supposed me to be deluded to have endeavored in a proper and affectionate manner to have reclaimed me-I was left to all kinds of temptations; and, mingling with all kinds of society, I frequently fell into many foolish errors, and displayed the weakness of youth, and the foibles of human nature. ${ }^{1}$

Joseph's love and appreciation for children and youth also derived from his experience growing up in a large and close family. When he married, he and his wife, Emma, created a home that welcomed natural and adopted children. Like many others of that era, they lost several infant children to fatal illnesses. During that time the Lord revealed to Joseph that children who die in infancy are saved in God's kingdom. In addition, he was given revelations concerning the potential for marital and parent-child bonds to last beyond the grave.

Given Joseph Smith's early spiritual and social experiences, his devoted attention to children, and the revelations he received about the divine nature and potential of children and about eternal families, it should not be surprising that Mormonism highly values spiritual development in children and youth-particularly in the context of home and family life. ${ }^{2}$ Indeed, its doctrines, covenants, and practices focus on the value of each individual child and helping each to come to know, love, and serve God and His children on earth.

This chapter discusses how children and youth are understood in the Church of Jesus Christ of Latter-day Saints (LDS, Mormon, the Church of Jesus Christ). It focuses on how Mormonism supports and guides children in light of the threats of contemporary American life. In so doing, I address core theological beliefs pertaining to LDS children and youth, major religious practices and institutions involving children and youth, and common challenges faced by American LDS children and youth.

In my discussion here I will address the doctrines that all human beings are spirit children of heavenly parents with whom they lived before birth; that children have eternal potential to become like their heavenly parents; that children are born innocent; that children have moral agency that allows them to make moral choices; that beginning at age eight, children are held accountable for moral decisions; that children who die before they become spiritually accountable are saved; and that gender is part of one's eternal identity.

The beliefs and practice I discuss pertaining to youth comprise the following: youth have obligations to God and to their religious community, all youth are expected to abide by standards of sexual purity, male youth are 
expected to prepare themselves for future full-time missionary service, and young men and young women are taught to prepare themselves for marriage and family life as the most important religious duties on earth. Further, I will address these religious practices: the naming and blessing of infants; baptism and confirmation of eight-year-old children; ordination to the priesthood of twelve-year-old young men; and temple baptisms, endowments, and sealings of youth and young adults. Before addressing these issues, I identify myself in relation to Mormonism and provide a brief historical and demographic profile of the church.

The reader should know that this chapter is written from the perspective of an active and devoted Latter-day Saint. I was raised an Episcopalian and was an acolyte in that faith as a child. I converted to Mormonism at age nineteen. After serving an LDS mission in New England, I met and married my wife in the Salt Lake Temple and we are raising our seven children in the faith. I have served in various capacities in the church, including as the bishop of a congregation of Brigham Young University (BYU) students. Both my teaching and scholarship at BYU focus on religion and family, including working with other BYU scholars to edit two volumes on LDS marriage and family life. ${ }^{3}$ Therefore, I provide a believing insider's perspective on Latterday Saint children, youth, and family life.

\section{Historical and Demographic Profile}

The Church of Jesus Christ of Latter-day Saints was established in I830 in upstate New York. The church is considered a restoration of the church and gospel founded by Jesus Christ, which Latter-day Saints believe fell away after the apostles were martyred. From the beginning the Saints were persecuted for their beliefs and practices and were forced from one place to another, finally being led to the Rocky Mountains by Joseph Smith's successor Brigham Young. ${ }^{4}$

As of April 2008, the church had more than I3 million members in I7O nations. ${ }^{5}$ More than half of current church members live outside the United States, speak a language other than English, and are converts to the church. ${ }^{6}$ Now the fourth-largest and the fastest-growing major religious denomination in the United States, it has about 5.5 million American members. ${ }^{7}$ In addition to being the dominant faith in Utah (70 percent) Mormons constitute a significant minority of religious adherents in parts of several states in the intermountain West. ${ }^{8}$

On the basis of growth patterns and its unique doctrine and practice, sociologist Rodney Stark declared Mormonism a "new world faith" and projected a worldwide LDS church membership of more than 50 million by the year 2040. ${ }^{9}$ Religious scholar Harold Bloom correctly stated that Mormonism 
is as distinct from traditional Christianity as Christianity is from Judaism, or as Islam is from Christianity. ${ }^{\text {I0 }}$ Latter-day Saints are Christian (their first article of faith enjoins "faith in the Lord Jesus Christ"), but because their beliefs differ from those of traditional Christian theology (for example, they believe that Christ and God the Father are distinct beings), they are considered non-Christian by some other faiths.

\section{Core Theological Beliefs Pertaining to Children}

Core LDS beliefs pertaining to children concern the doctrines of God the Eternal Father, the Lord Jesus Christ, the nature of the human soul, and issues of parental responsibility for the child. A sacred thread running through all LDS beliefs and practices is that the purpose of life is for children and youth to prepare themselves to form eternal marriages and families.

Latter-day Saints believe that God is literally the eternal father of all human beings, who are considered "spirit sons and daughters of heavenly parents." "II God the Father is a glorified, perfected, omniscient, and perfectly loving and merciful being who has a glorified body of flesh and bones. Young LDS children are taught to pray to "Our Father in Heaven" or "Our Heavenly Father." They are taught to sing the song "I Am a Child of God."

What Latter-day Saints refer to as "Heavenly Father's Plan of Happiness" is the doctrine that guides all church programs, teachings, ordinances (sacraments), and policies. The church provides doctrine, covenants, and ordinances that help children and youth understand and live this plan. The divine plan centers on God's spirit sons and daughters coming to earth through birth so that they can experience mortal life and death; learn to distinguish good from evil and choose good; learn to keep God's commandments and serve Him; and make sacred covenants with God, especially the covenants of baptism and eternal marriage.

Latter-day Saints believe that all human beings are spirit children of heavenly parents (Heavenly Father and Heavenly Mother) and are therefore of infinite and eternal worth and believe that every human being has potential to become like their heavenly parents through the atonement of Jesus Christ and by obedience to the gospel of Jesus Christ. Latter-day Saints hold that the atonement of Jesus Christ is the means by which all people may be forgiven of their sins, become spiritually clean, and return to the presence of God. Because of the atonement of Jesus Christ, "little children," who have not yet arrived at the "age of accountability" (typically age eight) and those who, because of mental or emotional limitations, never become accountable before God for their own sins, are saved in the kingdom of God. Because of the atoning sacrifice of Jesus Christ, children are born innocent. If an infant or child dies before reaching the age of accountability (typically age eight), 
she or he is saved in the celestial kingdom-the highest of three "degrees of glory" or heavens. LDS scripture states that "every spirit was innocent in the beginning; and God having redeemed man from the fall, men became again, in their infant state, innocent before God." ${ }^{2}$

Latter-day Saints believe that God has granted moral agency or free will to every human being. Thus each child is taught that she or he may choose to believe in God and may "choose the right" through obedience. LDS beliefs and practices strongly emphasize the eternal importance of individual agency, so there are strong prohibitions against coercion in religious upbringing. Parents, leaders, and teachers are expected to exercise kindness, patience, longsuffering, love, and gentleness in all their dealings with their own children and with others of Heavenly Father's children (D\&C I2I:33-46).

Latter-day Saints believe that gender is part of a person's premortal, mortal, and eternal identity, and there are some gender-specific aspects of being an LDS child or youth. Many things are the same for both genders: boys and girls both are offspring of divine parentage, both have eternal potential to become like their heavenly parents, both are baptized and confirmed and take the Sacrament of the Lord's Supper each week, and both make sacred covenants in holy temples (more will be said about temples later).

The main gendered differences in LDS life involve priesthood and motherhood. Priesthood is conferred only on LDS boys and men. Priesthood's most important responsibilities involve marriage, fatherhood, and service to God's children. LDS boys and men are taught that the most important priesthood service they will ever do will be within their homes. Indeed, priesthood, marriage, and fatherhood are nearly inseparable in LDS doctrine and practice. Motherhood is considered coequal with priesthood and a holy responsibility and opportunity for daughters of God. LDS girls and young women are taught the eternal importance of the divine work they perform in nurturing and providing life to God's children as wives and mothers.

\section{Parental Responsibility for the Child}

Parents have the primary responsibility to nurture children. Children are considered to be God's children, and earthly parents have only a custodial relationship with their children unless and until parents and children are sealed in the temple and remain true to temple covenants throughout this life. Those covenants involve kindness, gentleness, and love toward children and youth. Parents are obligated to teach children and prepare them for baptism (D\&C 68:25, 27-28). A well-known passage from the Book of Mormon states: "And ye will not suffer your children that they go hungry, or naked; neither will ye suffer that they transgress the laws of God, and fight and quarrel one with another, and serve the devil . . . but ye will teach them to walk 
in the ways of truth and soberness; ye will teach them to love one another, and to serve one another."

In an oft-quoted passage from the Doctrine and Covenants, the Lord rebukes an early member of the church by saying, "But I have commanded you to bring up your children in light and truth. . . . You have not taught your children light and truth, according to the commandments; and that wicked one hath power, as yet, over you, and this is the cause of your affliction" (D\&C 93:40, 42).

Children are considered a parent's greatest "stewardship" or sacred responsibility, and Latter-day Saints believe that they will have to make an account before God about how they have treated their child (D\&C 72:3) and that only if they have been righteous on earth can they expect to have eternal association with their children, who will, like themselves, be mature adults in heaven (what Latter-day Saints call the celestial kingdom).

In addition, the First Presidency and Council of the Twelve Apostles, considered living prophets and apostles, have responsibility to teach and inspire all church members, including children. This is done through semiannual worldwide General Conference broadcasts from Salt Lake City to homes and church buildings throughout the world and through articles in three monthly magazines that many members subscribe to (the Ensign for adults, the New Era for youth, and the Friend for children).

\section{Major Practices and Institutions Involving Children and Youth}

Religious practices and institutions involving children and youth have been developed on the basis of these foundational doctrines. In this section I will address the following: core religious practices involving children, family religious practices, church institutions for children and youth, changes in childhood traditions, the role of the church at various stages in children's development, the ideal voice of children in the religious community, and changes in programs for children and youth over time.

There are several central religious practices pertaining to children, among them naming and blessing of children, baptism, confirmation, ordaining to the priesthood, missionary service, and temple endowments and sealings. In the Doctrine and Covenants it states, "Every member of the church of Christ having children is to bring them unto the elders before the church, who are to lay their hands upon them in the name of Jesus Christ, and bless them in his name" (D\&C 20:70). Typically the "naming and blessing" of a child is done by the father, who stands before the congregation together with other elders (often including the child's other adult male relatives). They encircle the infant while cradling her or him in their hands and the father names and blesses the child by the power of the priesthood he holds. 
LDS children are baptized by immersion, typically at the age of eight. Most children raised in an LDS home are baptized by their father. However, the child may also be baptized by a grandfather, uncle, older brother who has the authority, or any other person who holds the priesthood. Following baptism the child is confirmed as a member of the church and is given the Gift of Holy Ghost by the laying on of the hands of one who holds the priesthood-again, typically this is performed by the child's father.

For LDS boys who have been baptized, the following four years are a time of preparation to be ordained as a Deacon in the Aaronic priesthood at age twelve. Boys are ideally ordained by their fathers. Fathers who hold the priesthood (nearly all LDS fathers) will ordain their sons to various offices of the priesthood beginning when the boys are age twelve and continuing until the father ordains the son as an Elder in the Melchizedek priesthood when the latter is age eighteen or nineteen. Ordinations can create a powerful intergenerational bond between fathers and sons.

LDS temples are where the most sacred covenants and ordinances take place-those that "seal" or eternally bind husband to wife and child to parent. All programs and curricula in the LDS church are intended to help prepare children and youth to be willing and able to make and keep these covenants. Temple sealings are the crowning ordinance in LDS life and foster a profound sense of closeness among family members.

Latter-day Saints believe that when Jesus said to the apostle Peter that "whatsoever ye shall bind on earth would be bound in heaven" (Matt. I8:I8), he was referring to the sealing powers of the priesthood that Peter received from Jesus. Joseph Smith received these same sealing powers through angelic ministration (D\&C IIO:I2-I6). Joseph taught that the "sealing powers" manifest in LDS temples exist in order to forge eternal family bonds that allow family members to be bound to each other on earth and in heaven. If a child's parents had made the covenant of marriage by being sealed in the LDS temple "for time and all eternity" before the child was born, then the child is considered to be "born in the covenant" and is born already sealed to faithful parents. Beyond salvation the most important spiritual blessing desired by most of those who convert to the LDS church is to go to the temple to be eternally sealed as a couple and family.

\section{Religious Practices in the Home}

By far the most important institution for the religious upbringing of LDS children and youth is the home. The home-based religious practices pertaining to children that will be addressed here involve family prayer, family scripture study, family home evening, father's blessings, family service, family work, and family history and genealogy. Of course, not all LDS parents 
perform their religious responsibilities and not all LDS families observe the practices mentioned below. But active LDS parents and families believe that they should observe these principles and practices. LDS children and youth are taught to pray to their Heavenly Father at least daily and preferably twice a day (morning and evening). LDS families are also strongly encouraged to hold family prayer daily. Personal and family study of scriptures is strongly encouraged. Most LDS families attempt to maintain this practice but many find it difficult, especially with increasing family activities that characterize many families with several children of varying ages.

LDS families are strongly encouraged to hold a weekly family night (typically on Monday evening) called Family Home Evening, involving gospel instruction, prayer, singing of hymns, family recreational activity, and refreshments (treats of some kind). LDS fathers are encouraged to give father's blessings to their children at regular times (birthdays, beginning of the school year) and trying times (a child's illness or discouragement). A father's blessing involves the father laying his hands on his child's head and pronouncing words of love, inspiration, comfort, counsel, and encouragement. These blessings tend to promote increased bonds between fathers and their children. ${ }^{\mathrm{I}}$

Individuals and families are encouraged to provide meaningful service. Many LDS families try to involve their children and youth in establishing patterns of service for their fellow Mormons, neighbors and friends, or both. Mormons are taught the importance of work. Many families try to involve their children and youth in meaningful work to develop their character and teach them to set goals and work toward achieving them.

Latter-day Saints emphasize family history, genealogy, and temple work. This involves searching out one's ancestors, writing up their history, and then going to the temple to do vicarious baptisms and temple sealings for these ancestors so that deceased individuals may be saved, couples may be married eternally, and generations may be sealed together eternally.

\section{LDS Institutions for Children and Youth}

Although it would be difficult to overstate how important family example and home instruction is, the church maintains a number of important efforts to complement and supplement family efforts. Much of LDS religious life is focused on children's development. There is clear and orderly progression for children and youth with clear rites of passage. Parents are often called to teach and lead their children in the Primary and youth programs of the church.

This section covers LDS institutional programs for children and youth. Of course, not all LDS kids are actively involved in church programs, and the 
degree of influence on children and youth depends both on the quality of adults leading the programs and on the personal traits and choices of the child. I will discuss the following programs: Children's Primary, Young Men and Young Women, and Seminary.

The Primary is an organization that provides religious instruction for children aged three to twelve. Primary classes are held for two hours each Sunday. Each quarter a Saturday activity is held. The curriculum has been developed with consultation from child development experts and is developmentally appropriate. At age eighteen months, children enter the Nursery, where they engage in supervised play and religious songs, stories, and activities. Children enter the Primary organization at age three and advance into new classes each year.

The first major rite of passage for a child is baptism and confirmation at age eight. Parents feel an obligation to prepare their children well for this important event and most children are excited to be baptized. The Primary curriculum for children before age eight is oriented toward helping the child learn the basic doctrines and covenants they need to know and accept to be baptized and then to make righteous choices. In the same way that other Christian children and youth wear jewelry carrying the abbreviation WWJD (What Would Jesus Do) many LDS children and youth wear a ring showing the abbreviation CTR (Choose the Right) to help them remember to exercise their moral agency righteously.

From age eight to twelve, children focus on an increasingly sophisticated and deepened understanding of gospel principles and practices. As they approach the age of twelve, they become more excited to graduate from Primary and become a Young Woman or a Young Man. The Young Men and Young Women programs provide Sunday instruction and weekly weeknight activities for youths aged twelve to eighteen. The Young Women use the church's Personal Progress program and the Young Men use the church's Duty to God program.

At age twelve girls enter a class for young women called Beehives and boys are ordained Deacons in the Aaronic priesthood. At age fourteen young women become Mia Maids and young men are ordained Teachers. At age sixteen young women become Laurels and young men are ordained Priests. Another major milestone that occurs at age sixteen is that young women and young men now are allowed to date-although they are encouraged to date in groups to avoid "pairing off." They are taught to not engage in any sexual relations until marriage.

Seminary is a program involving daily religious instruction for high school-aged youth. In Utah and some parts of other states with a large concentration of LDS youth, schools offer "released-time" Seminary where students take a religion class during regular school hours. In most places however, 
LDS high school students attend Seminary before the school day begins. During their four years of Seminary, with fifty minutes of class each weekday, a four-year Seminary graduate will have spent more than five hundred hours in focused study of the Old Testament; the New Testament; the Book of Mormon; and LDS Church History, including the Doctrine and Covenants.

\section{The Voice of Children and Youth in the Faith Community}

Rather than having a pastor who delivers a sermon each week, LDS Sunday gospel instruction is conducted by members of the ward. In addition, each month a "Fast and Testimony Meeting" is held where anyone-of any age-who desires to stand and share their religious beliefs and experiences with the congregation may do so. LDS children begin giving "talks" (short prepared sermons) in Primary at age three. Most LDS families involve their children in giving lessons in Family Home Evenings and so children learn to prepare and deliver messages, talks, ideas, and activities-often using some type of visual aid to assist them.

After children become Young Women and Young Men at age twelve they typically give one or two talks each year before the entire congregation. Thus, the average LDS person will have given dozens of talks by the time she or he becomes an adult. Each of the three age groups of Young Women and Young Men (twelve and thirteen, fourteen and fifteen, and sixteen and seventeen) has a president that leads and directs activities (there are a total of six presidents). This responsibility changes about every six months so that by the time individuals leave the youth program of the church they have likely served as a president (or counselor to a president) more than once. The presidents conduct weekly meetings on Sunday and on a weeknight. Each month these six presidents meet with the bishopric of the ward (a bishop and his two counselors) to plan activities, discuss the needs and desires of those they are responsible for, and receive guidance from the bishop and other youth leaders.

Thus most LDS children and youth become fairly competent and confident at public speaking. They learn how to speak, share strongly held beliefs, conduct meetings, advocate for their fellow youth with adult leaders, speak with those not of their faith, and in other ways raise their voice and lead groups.

\section{Changes in Childhood Education}

Over time there has been great stability and consistency in core doctrines and practices. However, given dramatic societal changes, the LDS church has also increased emphasis in some things and shifted its focus in some ways. The church's programs and instruction for children and youth have 
increased attention, beginning from an early age, on the importance of marriage and family life. Plural marriage was practiced in the early church but was discontinued in I890. ${ }^{14}$ There also has been increased emphasis on preparing LDS children and youth to attend the temple to perform vicarious baptisms for deceased ancestors. Youth begin attending the temple at age twelve and typically attend at least once a year with their youth group and are encouraged to attend with their parents. Finally, every LDS young man is expected to prepare himself to serve a two-year full-time mission when he turns nineteen. However, while a mission was once considered a kind of rite of passage for LDS young men, in recent years church leaders "raised the bar" on qualifying for full-time missionary service so that those who have significant physical, mental, emotional, or spiritual limitations are now "honorably excused" from full-time missionary service. Because missionary service is considered a priesthood responsibility, young women are not expected to serve but may do so if they choose (for eighteen months beginning at age twenty-one).

There also have been recent innovations in the use of media for children and in education. In the past few decades the church has increased the degree and sophistication of media products oriented toward children and youth. Many videos, magazines, pamphlets, films, and Web sites (for example, www.lds.org and www.mormon.org) have been produced to teach young people the gospel and prepare them for the strong opposition to some of their basic religious beliefs and practices that they will experience from contemporary American culture. Furthermore, LDS scripture states that "the glory of God is intelligence" (D\&C 93:36). Thus, like the Jewish community (see Dorff, this volume), Latter-day Saints have always valued education for children and youth. But recently there also has been increased emphasis on getting as much education as possible to enable LDS youth to be well prepared for the increasingly competitive and dynamic labor market.

\section{Common Challenges Faced by American LDS Children and Youth}

Common challenges faced by LDS children and youth include the child's obligations to parents and community, sexual chastity in contemporary culture, and perceptions of the threats and opportunities of American society for children and youth.

Children are taught that the gospel of Jesus Christ is about serving and even sacrificing for others. Contemporary American parents are surrounded by a popular culture that encourages them to provide their children with a continual supply of amusement and material possessions. Parents are expected to make sacrifices for their children but are not encouraged to ask their children to make meaningful sacrifices in turn. Therefore, requests 
from parents and church leaders for children and youth to give up valued personal time, activities, possessions, and status for religious reasons is not easy; sacrifice is a form of "countercultural" activity.

Latter-day Saint parents teach their children that God has asked them to sacrifice personal time, money, energy, comforts, and "things of the world." Children are expected to "honor thy father and thy mother" (Exod. 20:I2). Children are asked to keep the commandments and prepare themselves to make and keep sacred covenants. At age eight, children make the covenant of baptism, which involves covenanting to take upon oneself the name of Christ, keep His commandments, always remember Him, and comfort those who need comfort. Practically, this involves attending church, saying personal prayers, being honest, paying tithing (Io percent of income), keeping the Sabbath day holy (refraining from work or shopping on Sunday), and obeying parents.

Young Women often perform service for their communities, for example, engaging in disaster relief in LDS efforts to get aid to people stricken by natural calamities, visiting elderly and shut-in members, working in homeless shelters, and performing many other types of service. Young Men have additional significant priesthood responsibilities, among them preparing and administering the Sacrament (of the Lord's Supper) to the congregation each week, going to the homes of members each month to receive fast offerings (free will offerings to aid the poor given by those who fast for two meals or twenty-four hours), making monthly "home teaching" visits to the homes of two to four families to inquire about their well-being and deliver a message from church leaders, and performing various types of service in their communities. Most Mormon children and youth attend public schools, although there are some who homeschool or attend private schools. LDS youth tend to be very involved in extracurricular activities. One of the challenges is that many LDS youth are extremely busy and some are quite stressed from their efforts to fulfill various personal, family, educational, and church obligations. ${ }^{15}$

In contemporary American popular culture, sexual experience is regarded by many as a natural, normal, and desirable part of growing up. However, LDS children and youth are taught to obey the "law of chastity," which prohibits all sexual activity (including masturbation) before (and outside) marriage. Obviously, as children reach adolescence this issue becomes more challenging for them. Many counsel with their bishops (lay congregational leaders) about how to "keep morally clean" and resist sexual temptations, which come from many directions. This focus on chastity is a significant part of the church experience of most LDS youth, as they will hear and read many talks and lessons and articles from church magazines on this topic during their teens. Those who transgress the law of chastity are 
encouraged to repent of sexual sin by confessing to God and to their bishop, who will help them overcome their guilt and strive to avoid repeating the sin. While contemporary America is more religious than other modern Western industrialized nations, popular culture is aggressively secular. Like many other religious people, Latter-day Saints are deeply concerned about the general decline of standards and values upholding religion, marriage, and family. They are particularly concerned about the increase in violence, sexuality, and brutality in contemporary media directed toward children and youth. ${ }^{16}$

Latter-day Saints believe that children and youth face several threats from American society, including excessive materialism, radical individualism, unbridled hedonism, use of harmful substances, and negative influences from popular culture. American culture preaches a gospel of material success, which requires working long and hard in order to be able to afford the newest and best products and services. In contrast, the LDS church teaches members to pay tithing (as noted earlier, Io percent of income) for the building up of the church, to fast and make generous "fast offerings" each month to help the poor in their congregation and throughout the world, and to contribute to the missionary and humanitarian aid programs of the church. LDS youth are strongly encouraged to work and save to pay for as much of their full-time mission expenses as possible (about ten thousand dollars for a two-year mission). Children are taught to pay tithing from an early age. Many tithe on their allowance, babysitting income, and income from part-time jobs in high school.

American society is highly individualistic and encourages children and youth to reject authority and do whatever they want to do. In contrast, the LDS Church emphasizes obedience to God and focus on social groups, such as the family and the "ward family" (fellow congregants). Much time and energy is spent serving others and denying the self in order to please God and build His church and kingdom. Although many LDS children and youth have an admirable orientation to others and to causes beyond themselves, the siren song of radical individualism calls to them on a daily basis and not all are able to resist its allure. Latter-day Saints see American society as strongly oriented toward physical and emotional pleasure. Commercials portray personal pampering that everyone is entitled to. Latter-day Saint life is intended to be joyous and positive and to include wholesome recreational activities. Joseph Smith taught that fun, dancing, playing instruments, and recreation are part of the joyful religious life. There is no ascetic tradition in LDS life and Mormon children and youth are likely to participate in many of the same recreational and artistic activities that other American kids do. However, LDS children and youth are taught about the serious problems that attend the use of illicit substances and sexual activity outside marriage. They 
are also taught to avoid certain kinds of entertainment, such as X- or R-rated films, sexually explicit or violent music and video games, and pornographic content on the Internet and in other media.

Many American youth experiment with and become addicted to various substances as part of growing up. LDS children and youth are taught to obey the "Word of Wisdom," which requires abstaining from alcohol, tobacco products, drugs, coffee, tea, and any other addictive or harmful substance. Like the laws of Kashrut that distinguish Jewish children and youth from their non-Jewish and nonobservant peers, adherence to the Word of Wisdom distinguishes LDS children and youth from their non-LDS peers and raises many opportunities for LDS to explain their faith and stand up for their beliefs. Of course some LDS youth are teased or shunned by their peers, but most find a group of friends who respect their beliefs and practices and support them in their lifestyle.

American media places a never-ending series of pop celebrities in front of children and youth. These celebrities (musicians, sports figures, actors, and so on) often target children and youth to entice a type of "worship" through various forms of "devotion" such as watching and listening to them; copying their clothing, hairstyle, language, and mannerisms; paying for their products; posting their image on the walls of bedrooms or on computer desktops; and adopting their philosophies. In contrast, LDS parents, leaders, teachers, and written materials encourage youth to chose heroes from the Scriptures, the history of the church, the child's ancestors, or contemporary sports and entertainment figures who uphold standards of virtue.

\section{How Are LDS Kids Doing Spiritually?}

Despite these challenges, American LDS children and youth have many opportunities to live their faith and grow spiritually and in other ways. I conclude by presenting data addressing how LDS kids are doing in contemporary America. Recently, a national study of the spiritual and religious lives of American teens from numerous faith communities was reported in the book Soul Searching. ${ }^{17}$ This study of 3,370 teens, by University of North Carolina at Chapel Hill sociologists Christian Smith and Melinda Denton (neither of them LDS), found that LDS youth were highly involved with and committed to their faith. The study compared youth from various faiths on a variety of spiritual and religious variables. Below is a summary of the findings (with page numbers) from Soul Searching:

Mormon teens are the most likely among all U.S. teens to hold religious beliefs similar to those of their parents (35).

Seventy-one percent of Mormon teens attend church at least weekly (38). 
Mormon teens are highest in the importance of their faith shaping daily life and major life decisions (40).

Mormon and black conservative Protestant teens are the most likely to hold traditional, biblical religious beliefs (44).

Mormon teens were highest in having a very moving or powerful spiritual experience and highest in reporting they had "ever experienced a definite answer to prayer or specific guidance from God" (45).

Mormon teens were the most likely to report that they denied themselves something as a "spiritual discipline" (46).

Mormon teens appear to pray the most often (47).

Mormon teens reported being the most involved in religious youth groups and were the most likely to claim to be leaders in their youth groups (53).

Families of Mormon teens appear to talk about religious and spiritual matters the most (55).

Mormon, black Protestant, and conservative Protestant teens are most likely to pray with their parents (55).

Mormon teens (23 percent) are most likely to frequently express their faith at school (59).

Mormon and Jewish youth reported noticeably higher levels of pressure and teasing from peers than did Christian teens (59).

The number of nonparent adults who played a meaningful role in a teenager's life was noticeably higher for Mormons (6I).

Mormon youth were the highest percentage (83 percent) reporting that they anticipated attending the same type of faith community when they were twenty-five years old and the lowest percentage ( 2 percent) to say they anticipated attending "a different kind of congregation" (66).

I believe that Kenda Dean, a Methodist scholar of youth ministry at Princeton Theological Seminary, correctly interpreted these data by proposing that Mormonism provides LDS teens with "a consequential faith" characterized by (I) a substantive doctrine of God, or "a creed to believe"; (2) a community of consequence, or "a place to belong," which for Mormons is "family"; (3) a morally significant universe, or "a call to live out"; and (4) the opportunity of being asked to contribute to God's ultimate transformation of the world, or "a hope to hold on to." 18

\section{Conclusion}

Latter-day Saints believe that their doctrine and practice were revealed by a loving Father in Heaven to ancient and modern prophets in order to help His children return to Him as families to live with Him and become like Him. Latter-day Saint children and youth are taught by parents and living 
prophets and apostles that they are on earth to learn to prepare for eternal life. Eternal life centers on marriage and family life.

Contemporary American LDS children and youth find themselves surrounded by a popular culture that actively opposes many of the basic beliefs and practices they hold dear. Latter-day Saints believe that God has restored ancient truths and reveals additional truths to guide parents and religious leaders in teaching children and youth. In their homes, churches, and temples LDS children and youth seek to worship and serve God and fulfill their Heavenly Father's plan of happiness for His children.

\section{ACKNOWLEDGMENTS}

I am grateful to Jenet Jacob, Raymond Bucko, Mary Dollahite, Loren Marks, and Jeff Hill for helpful questions and suggestions on a previous draft.

\section{NOTES}

I. Pearl of Great Price, Joseph Smith History (Salt Lake City, UT: Church of Jesus Christ of Latter-day Saints), I:28.

2. For information on Joseph Smith's family life, see David C. Dollahite and E. Jeffrey Hill, "Shared Leadership in the Home: Principles from the Lives of Joseph and Hyrum Smith," in Joseph and Hyrum Smith: Lessons in Shared Leadership, ed. Mark E. Mendenhall, Hal B. Gregersen, Jeffrey S. O’Driscoll, Heidi S. Swinton, and Breck England (Provo, UT: BYU Religious Studies Center, forthcoming).

3. See Craig H. Hart, Lloyd D. Newell, Elaine F. Walton, and David C. Dollahite, eds., Helping and Healing Our Families: Principles and Practices Inspired by "The Family: A Proclamation to the World" (Salt Lake City, UT: Deseret Book, 2005). See also David C. Dollahite, ed., Strengthening Our Families: An In-depth Look at the Proclamation on the Family (Salt Lake City, UT: Bookcraft, 200o).

4. For an excellent history written by an award-winning non-LDS historian see, Jan Shipps, Mormonism: The Story of a New Religious Tradition (Urbana: University of Illinois Press, I987). See also Richard L. Bushman, Joseph Smith: Rough Stone Rolling (New York: Knopf, 2005).

5. Ensign 38, no. 5 (2008): 25. Ensign is the official magazine of the LDS Church.

6. Elder Henry B. Eyring, "Hearts Bound Together" (address given at I75th annual conference of the Church of Jesus Christ of Latter-day Saints, Salt Lake City, UT, April 3, 2005), http://lds.org/conference/talk/display/o,5232,49-I-520-26,oo.html.

7. Eileen W. Lindner, ed., Yearbook of American and Canadian Churches (Nashville, TN: Abingdon Press, 2005).

8. Dale E. Jones, Sherri Doty, Clifford Grammich, James E. Horsch, Richard Houseal, Mac Lynn, John P. Marcum, Kenneth M. Sanchagrin, and Richard H. Taylor, Religious Congregations and Membership in the United States, 2000 (Nashville, TN: Glenmary Research Center, 2002). See especially maps at 547, 562.

9. For a sociological analysis of Mormon growth, see Rodney Stark, The Rise of Mormonism (New York: Columbia University Press, 2005). 
IO. Harold Bloom, The American Religion: The Emergence of the Post-Christian Nation (New York: Simon and Schuster, 1992).

II. First Presidency and Council of the Twelve Apostles of the Church of Jesus Christ of Latter-day Saints, "The Family: A Proclamation to the World," Ensign 25, no. II (I995): IO2.

I2. Doctine and Covenants 93:38. The Standard Works (accepted canon of scripture), include the Holy Bible, the Book of Mormon, the Doctrine and Covenants (hereafter cited as D\&C), and the Pearl of Great Price.

I3. David C. Dollahite, "Fathering for Eternity: Generative Spirituality in Latter-Day Saint Fathers of Children with Special Needs," Review of Religious Research 44 (2003): 237-25I.

I4. As part of the prophesied restoration of all things (Acts 3:2I; Eph. I:IO; Rev. II:3) to be accomplished in the last days and as an Abraham-like test (D\&C I32:28-37), Joseph Smith was commanded to practice plural marriage (polygyny). Polygyny was practiced by most Old Testament patriarchs (Abraham, Jacob, Moses, David).

I5. David C. Dollahite and Loren D. Marks, "Teaching Correct Principles: Promoting Spiritual Strength in Latter-Day Saint Young People," in Nurturing Childhood and Adolescent Spirituality: Perspectives from the World's Religious Traditions, ed. Karen M. Yust, Aostre N. Johnson, Sandy Eisenberg Sasso, and Eugene C. Roehlkepartain (Lanham, MD: Rowman and Littlefield, 2006), 394-408.

I6. David C. Dollahite, "Latter-day Saint Marriage and Family Life in Modern America," in American Religions and the Family: How Faith Traditions Cope with Modernization, ed. Don S. Browning and David A. Clairmont (New York: Columbia University Press, 2006), I24-I5O.

I7. Christian Smith with Melinda L. Denton, Soul Searching: The Religious and Spiritual Lives of American Teenagers (Oxford: Oxford University Press, 2005).

I8. Kenda Dean, "Numb and Numb-Er: Youth and the Church of "Benign Whateverism" (paper presented at the International Association for the Study of Youth Ministry, London, January 3-7, 2005). 